ENTREPRENEURSHIP AND SUSTAINABILITY ISSUES

ISSN 2345-0282 (online) http://jssidoi.org/jesi/

2020 Volume 7 Number 3 (March)

http://doi.org/10.9770/jesi.2020.7.3(15)

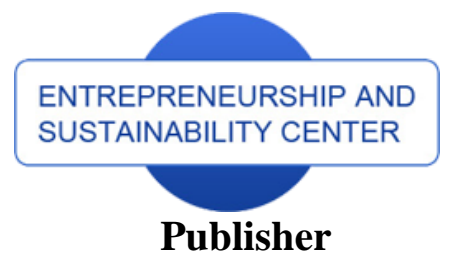

http://jssidoi.org/esc/home

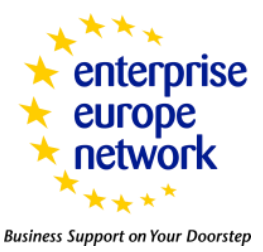

CASPA

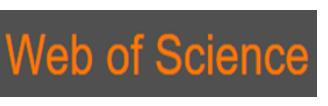

\title{
THE IMPACT OF MEGA-EVENTS ON URBAN SUSTAINABLE DEVELOPMENT
}

\author{
Gulnar Mirzayeva ${ }^{1}$, Oguz Turkay ${ }^{2}$, Nurkhodzha Akbulaev ${ }^{3}$, Fariz Ahmadov ${ }^{4}$ \\ ${ }^{1,3,4}$ Azerbaijan State University of Economics-UNEC, Economy and Business, Abbas Sahhat str., 45a, Baku, Azerbaijan \\ ${ }^{1}$ Sakarya University of Applied Sciences, Tourism Management, Camicedit/Pasha str., No:16, Sapanca/Sakarya, Turkey \\ ${ }^{2}$ Sakarya University of Applied Sciences, Gastronomy and Culinary Arts, Camicedit/Pasha str., No. 16, Sapanca/Sakarya, \\ Turkey \\ ${ }^{4}$ Azerbaijan State University of Economics-UNEC, International Center for Graduate Education, Abbas Sahhat str., 45a, \\ Baku, Azerbaijan

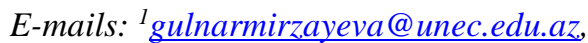 \\ ${ }^{1}$ gulnarmirzayeva8@gmail.com, ${ }^{2}$ turkay@subu.edu.tr, ${ }^{3}$ nurhodja_akbulayev@unec.edu.az,. ${ }^{4}$ f.ahmadov@unec.edu.az
}

Received 16 July 2019; accepted 10 December 2019; published 30 March 2020

\begin{abstract}
Mega-events have different types of effects for host cities or countries. The purpose of this paper is to identify the impact indicators of the Formula 1 Grand Prix in Baku, Azerbaijan from the perspective of tourism stakeholders and to investigate the effects of these impacts on the urban sustainability through the perceptions of stakeholders after the Formula 1 Grand Prix. The results indicated that environmental and social impacts exerted significant positive effects on urban sustainability. All positive dimensions of economic impact exerted significant positive effects on urban sustainability and 'prices rising' negative dimension exerted nonsignificant effects on urban sustainability. The results showed that except 'tourism infrastructure development' other positive dimensions (infrastructure development, protection of natural resources and cultural heritage) of environmental impact and only 'social welfare' positive dimension of social impact exerted significant positive effects on urban sustainability. This research contributes to policymakers by revealing the impacts of megaevents on urban sustainable development.
\end{abstract}

Keywords: urban sustainability; mega-events; stakeholders' perceptions; sustainable development

Reference to this paper should be made as follows: Mirzayeva, G., Turkay, O., Akbulaev, N., Ahmadov, F. 2020. The impact of megaevents on urban sustainable development. Entrepreneurship and Sustainability Issues, 7(3), 1653-1666. https://doi.org/10.9770/jesi.2020.7.3(15)

JEL Classifications: O11, O22.

\section{Introduction}

Sustainable development is the current imperative of the economic system's structural rearrangement. Consequently, an increase of the world countries' competitiveness is correlated with the economic growth, modernization of the economy and society in accordance with the socio-economic indicators of sustainable development (Dalevska, Khobta, Kavilinski, Kravchenko, 2019; Prakash, 2019). Mega-events have taken pride place in the urban agenda of contemporary metropolises. This current importance lies in the fact that the mega 


\section{ENTREPRENEURSHIP AND SUSTAINABILITY ISSUES}

ISSN 2345-0282 (online) http://jssidoi.org/jesi/

2020 Volume 7 Number 3 (March)

http://doi.org/10.9770/jesi.2020.7.3(15)

event be viewed as a catalyst for urban development of a metropolis, and an opportunity for affirmation them as global cities (Menezes and Souza, 2014). Mega-events play a major role in the development and marketing strategies of most destinations and are increasingly considered crucial for enhancing destination competitiveness. Mega-event research has steadily grown in number and diversity because of the tremendous influence of megaevents on the economy and image of host destinations (Lee, Lee, Park, 2014; Getz, 2008).

According to Hall (1992) cities and countries strongly compete for the chance of hosting events such as the Olympic Games, FIFA World Cup or a World Expo, because these events, have not only attracted an increasingly global audience, also seem to have shaped world tourism patterns, highlighting new tourism destinations (Fourie and Gallego, 2011).

From the moment the host country decides to bid for the event to the time of selection and throughout the preparation for the event hosting, there are opportunities to leverage the event to achieve long term goals. Event leveraging is defined as efforts to take advantage of potential development opportunities a mega sport event can bring in a number of areas such as economic, tourism, socio-cultural, environmental, sport and health (Kaplanidou, Emadi, Sagas, Diop, Fritz, 2016). The "Barcelona model" is constantly cited as the best example of use of a mega event as leverage for urban transformation and urban marketing to promote the city's image to the point of being considered a global city making it mandatory route of thousands of tourists every year (Menezes and Souza, 2014).

Whilst a megaevents occur over only few weeks, the preparation for them takes place over a number of years. A broad range of stakeholders contribute to these preparations, with a need to balance the desire of showcasing the city whilst maintaining as much continuity as possible for the resident population. A core element of this continuity involves the maintenance of the transport system to ensure the effective movement of goods and people around the city (Parkes, Jopson, Marsden, 2016).

Mega-event impact studies have concentrated largely on economic outcomes. At the same time, in a few studies economic, social and environmental impacts of mega-events were investigated together. The current study makes significant contributions to the literature and focuses on economic, social and environmental impacts of megaevents on sustainable development.

\section{Literature Review}

The future of contemporary society will be increasingly 'urban'. Cities are the main ground where 'the match' of social and economic development is being disputed (Maiello and Pasquinelli, 2015). Recent years have seen growing academic interest in the urban aspects of mega-events, especially with respect to their role as catalysts for mega-projects, magnets for investors and tourists and instruments of city marketing. Urban research on megaevents is generally concerned with the socio-spatial implications of event-led redevelopment, the impacts of mega-events on local politics and public policy, the economic legacy of mega-events and their role in city marketing (Broudehoux, 2017).

Hosting mega-events has significantly stimulated urban infrastructure investment and boosted urban transformation. Mega-events are events that draw substantial numbers of individuals to a location, placing the local environmental and infrastructure under great pressure, and bringing disruption to residents (Wu, Xun, Lin, 2016). Reports in favor of investment in an event generally overstate the benefit of job creation, too. Hosting an event will certainly present a need for labor for construction of event-related infrastructure, administration of the event's activities, maintenance of grounds and facility, security, and to prepare and sell a wide range of food, beverages, and souvenirs. The Sports Management Research Institute estimated the direct economic benefits of the U.S. Open Tennis tournament in Flushing Meadows, New York at \$420 million for the tri-state area, more 


\section{ENTREPRENEURSHIP AND SUSTAINABILITY ISSUES}

ISSN 2345-0282 (online) http://jssidoi.org/jesi/

2020 Volume 7 Number 3 (March)

http://doi.org/10.9770/jesi.2020.7.3(15)

than any other sports or entertainment event in any city in the United States. This sum represents $3 \%$ of the total annual direct economic impact of tourism for New York. The projected $\$ 6$ billion impact of the World Cup proposed for South Africa in 2006 suggested that soccer games and their ancillary activities would have represented over 4 percent of the entire gross domestic product of the country in that year (Matheson, 2006). Of course, there is an opportunity cost of creating new jobs for a mega-event: investment in some other public project or goal done with the potential for more robust levels of economic development-would also create jobs. Many of those would be permanent and thus the aggregate long-term demand for labor could be greater than what exists when a mega-event is held. It is extremely important to understand whether mega-events in developing countries can represent a stimulus for community participation in tourism development. In recent years several mega-events have been awarded to developing countries, in part to support or celebrate their development: For instance, 2010 Football World Cup (South Africa), 2012 European Football Cup (Poland and Ukraine) and 2012 Expo (Yeosu) (Lamberti, Noci, Guo, Zhu, 2011).

Urban development is understood as both a process of economic, spatial and social progress and a means whereby local governments formulate and execute public policies for economic growth (Wu et al, 2016). The Brundtland Commission's (The World Commission on Environment and Development) 1987 report entitled Our Common Future "led directly to the term 'sustainable development' passing into policy discourse, if not into everyday language". The report provides two such normative definitions. The first is often termed the Our Common Future definition, is explicitly defined sustainable development as development that meets the needs of the present without compromising the ability of future generations to meet their own needs (WCED, 1987; Redclift, 2005; Morse, 2008). The second, known as the "Three Pillars of sustainability" was implicitly identified within the report as a broader objective to link economic, social and environmental concerns (Abrahams, 2017).

Mega events have assumed a key role in urban and regional tourism marketing and promotion and in wider urban and regional development strategies. Although mega-events are generally built around non-tourism objectives (such as sport or cultural goals), public bodies are increasingly regarding them as a formidable instrument for the development of tourism. Mega-events are one-time events that typically generate profound positive and negative long-term impacts on host communities (Liang, Wang, Tsaur, Yen, 2016; Lamberti et al, 2011). Finally, megaevents are defined as large-scale, short-term and high-profile urban events which function as an engine for urban development (Wu et al, 2016).

Every mega-event hosted in a community usually has direct social and cultural impacts on the host community. Mega-events have the ability to intensify community pride, introduce new and challenging ideas and also help to revitalize the traditions of the host community. Major events can sometimes create unintended consequences which can hijack the agenda and determine the way the public perceives the event if not managed properly. Such consequences can be in form of substance abuse, bad behaviour by crowds and the increase in criminal activities (Etiosa, 2012). Events can cause unwelcome incursions and disruptions to the lives of locals. Further, since events concentrate large number of people into a small area, and require significant travel, there are ongoing concerns about their environmental footprint (Grix, 2014; Ekber and Mirzayeva, 2017). Events can also impact on the social life and structures of communities in various ways. An example of which can be car traffic which may impede the access to resident's homes, loss of amenities, cost inflation of goods and services, which can raise housing markets thereby impacting on the low-income groups (Allen, O’Toole, Harris, McDonnel, 2010)

It is worth noting in this case, the concern with creating environments that meet the diversity of individuals who reside in or visit the city in question. In this context, it is worth mentioning the example of the city of Barcelona where the 1992 Summer Olympic and Paralympic Games had a special significance in the struggle for the rights of Persons with Disabilities - DP (Pereira, Albuquerque, Portugal, 2014). 


\section{ENTREPRENEURSHIP AND SUSTAINABILITY ISSUES}

ISSN 2345-0282 (online) http://jssidoi.org/jesi/

2020 Volume 7 Number 3 (March)

http://doi.org/10.9770/jesi.2020.7.3(15)

Mega-events are also associated with various environmental impacts due to the vast amounts of construction materials, energy and resource use, waste generation, air and noise pollution during the construction of the event site, staging the event and post-event site redevelopment and operation. Environmental strategies for the megaevents have recently become a fundamental part of the overall events' sustainability management plans. Typically, they specify the actions that are going to be implemented in order to minimise negative environmental impacts resulting from the preparation and staging of the event (Parkes, Lettieri, Bogle, 2016). Many of the event impacts can be characterized as tangible and intangible (Kaplanidou \& Karadakis, 2010; Preuss, 2007). Among the tangible impacts, infrastructure development is the most characteristic example, while the intangible impacts often involve development of social capital (Gibson et al., 2014) and expanded business networking (Kaplanidou et al, 2016).

There is a twofold level of impact of mega-events on the hosting community: on the one hand, a mega-event impacts on the community as (i) it attracts a significant amount of public resources to build infrastructure, potentially modifying the environment, (ii) it leads to international exposure and media scrutiny, and (iii) by hosting large numbers of tourists, it generates a possible cultural contamination that is intrinsically linked to the significant opening up of an area towards tourism required by the event. On the other hand, mega-events are expected to generate economic externalities, such as the development of companies and organisations directly or indirectly serving the mega-event, and also non-economic impacts in the form of cultural legacies, variations to tourism culture and to the community's national and international perceptions (Lamberti et al, 2011).

Some scholars believe that the mega event only serves to exacerbate social problems and differences between residents of the host city, and they see the event as a strategy for urban renewal revolves around the discussion about who will benefit and that rare occasions result in some improvement for citizens. Other authors believe that the mega event allows the creation of an urban system capable of accelerating growth in the urban agenda and define it as a catalyst for urban transformation (Menezes and Souza, 2014).

Mega-event impact studies have concentrated largely on economic outcomes (Werner, Dickson, Hyde, 2015). Fourie and Gallego's (2011) research result implies that by hosting a mega-sport event countries would increase their tourist arrivals by 8.1\%. The Expo 2012 Yeosu Korea attracts about 8.2 million visitors from 104 countries, has an economic effect of USD 11.09 billion, and creates 79,000 employees (Lee et al, 2014; Akbulaev and Mirzayeva, 2020). There is also another important aspect associated with mega-events that a cost-effectiveness evaluation must consider. The need for a subway in Athens, for example, or an enhanced airport with improved roadway connections to the central city were recognized long-before a proposal for the Olympics was formulated. The existence of the games and the desire to make them successful sometimes creates the political will to satisfy long-standing infrastructure needs (Mills and Rosentraub, 2013). During the last ten years Rio has been hosting not only sport events, but also other mega-events, such as the 2012 Rio +20 and the 2013 World Youth Day. This series of large-scale events has been determining the urban development agenda for over a decade, with social and economic impacts not just on Rio but also on the whole country (Maiello and Pasquinelli, 2015). Absalyamov's (2015) research result implies that cultural, entertainment and sports international events have a much greater sustainable positive impact on the socio-economic situation in the host-regions. Absalyamov's (2015) research results show that:

$\checkmark$ International mega-events have influence on individual sectors of the economy and social life of the host countries;

$\checkmark \quad$ Large global events positively affect the level of foreign economic activity and the dynamics of economic development;

$\checkmark$ Mega-events have a positive impact on the preservation of cultural heritage. 


\section{ENTREPRENEURSHIP AND SUSTAINABILITY ISSUES}

ISSN 2345-0282 (online) http://jssidoi.org/jesi/

2020 Volume 7 Number 3 (March)

http://doi.org/10.9770/jesi.2020.7.3(15)

The findings of Caiazza and Audretsch's (2015) study demonstrates that; 'Respondents indicated that after the event, the level of interest had decreased. Before the games, residents held some expectations of the economic, socio-cultural and political benefits for their communities, although they were aware of the fact that these benefits would come with a cost. Consequently, residents treated the outcomes as losses because they were not significant enough to justify the expense'. Although sporting events may make a great contribution to positive publicity or to the image of city tourism policymakers should understand that residents are more concerned about their day-byday problems related to employment and crime.

According to the study results of Ntloko and Swart (2008) 73.5\% agreed that the event provided a chance to meet new people, increases entertainment opportunities for locals $(68.5 \%)$, provided an opportunity to have fun with family and friends $(65 \%)$ and provided an opportunity to attend an interesting $(62 \%)$. These results show that the event has an entertainment value. Nearly half of the respondents (47.5\%) agreed to strongly agreed that only some members of the community benefited from the event, while $53.5 \%$ agreed to strongly agreed that the event increased interaction between locals and tourists.

The study results of Kim, Gursoy and Lee (2006) showed that all positive dimensions (i.e. economic benefits, investment benefits, and consumer habits) of economic impact exerted significant positive effects on urban sustainability, whereas all negative dimensions (i.e. rising prices and wasted investment) exerted nonsignificant effects on urban sustainability. The statistics showed that all dimensions (i.e. infrastructure development, tourism infrastructure development, protection of natural resources and cultural heritage, and energy conservation) of environmental impact exerted significant positive effects on urban sustainability. The statistics showed that all dimensions (i.e. community development, service and reception, and social welfare) of social impact exerted significant positive effects on urban sustainability.

Urban sustainability can be measured from the aspects of ecological sustainability, water resources use, economic efficiency, resource self-sufficiency, environmental loading, living comfort, transport efficiency, environmental management, social welfare and public safety, and education. Mega-event generates numerous positive and negative impacts for the host city (Kim et al., 2006; Zhou and Ap, 2009). These positive economic, environmental, and social impacts are beneficial for urban sustainability. For example, positive economic impact may increase the economic efficiency and resource self-sufficiency for the hosting city. Positive environmental impact may promote the ecological sustainability, water resource use, environmental loading, transport efficiency, and environmental management for the hosting city. Positive social impact may enhance the living comfort and social welfare and public safety (Liang et al, 2016).

Therefore, in this research, based on literature review we infer that a mega-event creates both positive (economic benefits, investment benefits, infrastructure development, community development etc.) and negative impacts (prices rising, wasting investment etc.) on the host city. These effects can be evaluated regarding economic, environmental, and social impacts according to long-term effects, and positive mega-event impacts positively affect urban sustainability. Thus, based on previous research results the following hypotheses were proposed:

H1. Positive mega-event economic impact positively affects urban sustainability

H2. Positive mega-event environmental impact positively affects urban sustainability

H3. Positive mega-event social impact positively affects urban sustainability

The hypothesised framework for this analysis is presented in Figure 1. The effects of mega event impacts on the urban sustainability are encapsulated in $\mathrm{H} 1-\mathrm{H} 3$. 
Figure 1. Hypothesised framework

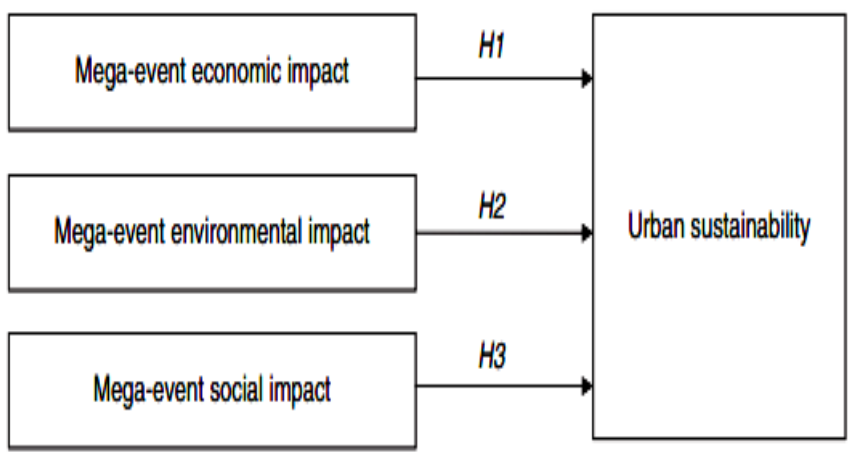

\section{Research methodology}

\subsection{Questionnaire design and variables}

In order to achieve research objectives, the authors conducted a literature review and prepared a new scale based on previous scales. This process resulted in 14 indicators of economic impact, 10 indicators of social impact, 9 indicators of environmental impact and the authors developed a 10-dimension/33-indicator mega-event impact measurement scale A five points Likert scale was used to measure variables with assigned value ranking from highest to lowest 5 "strongly disagree" to 1 "strongly agree".

\subsection{Sample selection and data collection}

Semi-structured interviews were the focal source in this research and a formal online survey complemented the findings. The 71 stakeholders represented key hotels, travel agencies, restaurants/coffees and entertainment centres of Baku. In this article judgment sampling is used. A judgment sample is a type of nonprobability sample, which is selected on the basis of knowledge of a subject matter expert with knowledge of the process being studied (Perla and Provost, 2012:171). In this research were selected the companies which increased occupancy rate and revenues during the Formula 1 Grand Prix event. The whole sample was tried to be reached. The interviewees' job positions ranged from higher-level decision-makers in their organizations such as General Secretary, CEO and director, to middle management positions like managers and department heads. A total of 71 semi-structured interviews were conducted face to-face or via phone.

The phone response to the questions provided some insights but it was not as rich as the face to face interviews. Interview locations were chosen according to the availability of the interviewees. The interviews were informed about mega-events' impacts and urban sustainable development. Interview questions were developed after an extensive review of the relevant literature review. The interviews were audio-taped and notes were taken to capture important thoughts. Examples of the interview questions include 'How has Formula 1 Grand Prix impacted on occupancy rate in the organization?' and 'How has Formula 1 Grand Prix impacted on revenue?'.

Within a few days after their post-event interview, all 71 participants received a link to participate in a relevant online survey. We excluded 1 invalid questionnaires, resulting in 70 valid responses. Seventy surveys were evaluated. The survey questions were drawn from the study of Liang et al. (2016). To ensure measurement validity of the original scale, a dichotomous pilot test was conducted by 12 experts, who had researched or 
ENTREPRENEURSHIP AND SUSTAINABILITY ISSUES

ISSN 2345-0282 (online) http://jssidoi.org/jesi/

2020 Volume 7 Number 3 (March)

http://doi.org/10.9770/jesi.2020.7.3(15)

handled the case of the mega-events, to determine whether these indicators were suitable. The reliability of the original scale was 0.845 . Prior to conduct to the real survey, a pilot study of 17 participants was done before a few weeks earlier from opening Formula 1 Grand Prix to ensure that the research instrument is suitable for respondents to gather data. For pilot testing was selected seven hotels, four travel agencies, 4 restaurants and 2 entertainment centres. After pilot testing consumer habits, energy conservation dimensions and enhanced innovation, enhanced pride of residents, enhanced reception standard, water resources utilisation, resource selfsufficiency indicators were removed from the survey. Data were collected between June and July 2019.

\section{Findings}

The respondents included 70 per cent men, and 60 per cent of the respondents were married. Most respondents (52.9 per cent) were university educated (bachelor degree), and 31.4 and 25.7 per cent of them were 40-49 years of age and 50-59 years of age, respectively. According to the interview results, occupancy rate increased between 5 per cent and 20 per cent. Data gathered from the interviews indicates that the mega-events such as Formula 1 Grand Prix that are held in Baku provide a wide range of economic opportunities. The majority of the interviews indicated that these events increased revenue between 10 per cent and 25 per cent. Overall, 93 per cent of the interviews thought that mega-events were beneficial to their businesses and they want these events to continue.

The reliability was tested by SPSS software, the result of Cronbach's Alpha was 0.875. Tables 1-3 indicate that all of the measures were reliable, with Cronbach's $\alpha$ values greater than 0.70 , conforming to the internal consistency criteria (Liang all. 2016). The Cronbach's $\alpha$ value of economic impact (0.77) was lower than environmental impact (0.85) and social impact (0.84) were.

The mega-event economic impact statements outlined in Table 1 indicate a high level of agreement for "increased number of tourists" $(\mathrm{M}=4.73)$ and "increased tourism revenues" $(\mathrm{M}=4.64)$. Respondents expressed a high level of agreement towards the "prices rising" dimension $(\mathrm{M}=4.52)$. Items with lower mean scores were associated with "increased tax revenues" and "improved business investment".

Table 1. Descriptive statistics and reliability of mega-event economic impact

\begin{tabular}{|c|c|c|c|}
\hline Items & Mean & $\begin{array}{l}\text { Std. } \\
\text { Deviation }\end{array}$ & Cronbach's $\alpha$ \\
\hline Economic impact & & & 0.77 \\
\hline $\begin{array}{l}\text { Dimension } 1: \quad \text { economic } \\
\text { benefits }\end{array}$ & 4.30 & 0.31 & 0.76 \\
\hline $\begin{array}{l}\text { Increased employment } \\
\text { opportunities }\end{array}$ & 4.01 & 0.71 & \\
\hline Increased economic growth & 4.58 & 0.49 & \\
\hline Increased tax revenues & 3.51 & 0.58 & \\
\hline Increased number of tourists & 4.73 & 0.44 & \\
\hline Increased tourism revenues & 4.64 & 0.48 & \\
\hline $\begin{array}{l}\text { Dimension 2: investment } \\
\text { benefits }\end{array}$ & 4.04 & 0.48 & 0.71 \\
\hline Improved business investment & 3.80 & 0.73 & \\
\hline $\begin{array}{ll}\text { Increased } & \text { business } \\
\text { opportunities } & \end{array}$ & 4.01 & 0.71 & \\
\hline Improved public investment & 4.14 & 0.68 & \\
\hline $\begin{array}{l}\text { Increased } \\
\text { activities }\end{array}$ & 4.20 & 0.71 & \\
\hline Dimension 3: prices rising & 4.52 & 0.48 & 0.92 \\
\hline $\begin{array}{l}\text { Increased prices of goods and } \\
\text { services }\end{array}$ & 4.48 & 0.50 & \\
\hline Increased prices of real estate & 4.56 & 0.50 & \\
\hline
\end{tabular}


ENTREPRENEURSHIP AND SUSTAINABILITY ISSUES

ISSN 2345-0282 (online) http://jssidoi.org/jesi/

2020 Volume 7 Number 3 (March)

http://doi.org/10.9770/jesi.2020.7.3(15)

\begin{tabular}{llll}
$\begin{array}{l}\text { Dimension } \quad 4: \quad \text { wasting } \\
\text { investment }\end{array}$ & 4.30 & 0.42 & 0.70 \\
Increased financial burden & 4.58 & 0.49 & \\
Increased unused facilities & 3.86 & 0.70 & \\
Increased budget pre-emption & 4.45 & 0.50 & \\
\hline
\end{tabular}

The mega-event environmental impact statements outlined in Table 2 indicate a high level of agreement towards "improved city appearance" $(\mathrm{M}=4.78)$, "increased leisure facilities" $(\mathrm{M}=4.77)$ and "improved city road condition" $(\mathrm{M}=4.77)$. Respondents perceived a high level of agreement towards the tourism infrastructure development dimension $(\mathrm{M}=4.30)$. Items with lower mean scores were associated with "enhanced and improved sanitation facilities" and "increased number of hotel rooms".

Table 2. Descriptive statistics and reliability of mega-event environmental impact

\begin{tabular}{|c|c|c|c|}
\hline Items & $\mathrm{M}$ & SD & Cronbach's $\alpha$ \\
\hline Environmental impact & & & 0.85 \\
\hline $\begin{array}{l}\text { Dimension 1: infrastructure } \\
\text { development }\end{array}$ & 4.23 & 0.32 & 0.71 \\
\hline Improved city appearance & 4.78 & 0.42 & \\
\hline Improved city road condition & 4.77 & 0.42 & \\
\hline $\begin{array}{l}\text { Enhanced and improved } \\
\text { sanitation facilities }\end{array}$ & 3.14 & 0.35 & \\
\hline $\begin{array}{l}\text { Dimension } \quad 2: \quad \text { tourism } \\
\text { infrastructure development }\end{array}$ & 4.30 & 0.32 & 0.69 \\
\hline $\begin{array}{l}\text { Increased tourist information } \\
\text { facilities }\end{array}$ & 4.18 & 0.54 & \\
\hline Increased leisure facilities & 4.77 & 0.42 & \\
\hline $\begin{array}{l}\text { Increased number of hotel } \\
\text { rooms }\end{array}$ & 3.94 & 0.65 & \\
\hline $\begin{array}{l}\text { Dimension } 3: \text { protection of } \\
\text { natural resources and } \\
\text { cultural heritage }\end{array}$ & 4.22 & 0.39 & 0.87 \\
\hline $\begin{array}{l}\text { Enhanced efforts of } \\
\text { preserving natural resources }\end{array}$ & 4.18 & 0.39 & \\
\hline $\begin{array}{l}\text { Enhanced efforts of } \\
\text { preserving cultural heritage } \\
\text { resources }\end{array}$ & 4.18 & 0.42 & \\
\hline $\begin{array}{l}\text { Enhanced the efforts of the } \\
\text { restoration of historical } \\
\text { buildings }\end{array}$ & 4.28 & 0.48 & \\
\hline
\end{tabular}

The mega-event social impact statements outlined in Table 3 indicate a high level of agreement for "increased entertainment opportunity" $(M=4.78)$ and "increased events and activities" $(M=4.77)$. Respondents expressed a high level of agreement towards the "social welfare" dimension $(\mathrm{M}=4.64)$. Items with lower mean scores were associated with "enhanced community consciousness". 
ENTREPRENEURSHIP AND SUSTAINABILITY ISSUES

ISSN 2345-0282 (online) http://jssidoi.org/jesi/

2020 Volume 7 Number 3 (March)

http://doi.org/10.9770/jesi.2020.7.3(15)

Table 3. Descriptive statistics and reliability of mega-event social impact

\begin{tabular}{|c|c|c|c|}
\hline Items & $\mathrm{M}$ & SD & $\begin{array}{l}\text { Cronbach' } \\
\mathrm{s} \alpha\end{array}$ \\
\hline Social impact & & & 0.84 \\
\hline $\begin{array}{l}\text { Dimension } 1: \quad \text { community } \\
\text { development }\end{array}$ & 4.40 & 0.32 & 0.86 \\
\hline $\begin{array}{l}\text { Enhanced community } \\
\text { consciousness }\end{array}$ & 3.92 & 0.63 & \\
\hline $\begin{array}{l}\text { Enhanced } \\
\text { development }\end{array}$ & 4.60 & 0.49 & \\
\hline $\begin{array}{l}\text { Enhanced public affair } \\
\text { participation }\end{array}$ & 4.61 & 0.49 & \\
\hline $\begin{array}{l}\text { Dimension 2: service and } \\
\text { reception }\end{array}$ & 4.50 & 0.44 & 0.86 \\
\hline Enhanced spirit of hospitality & 4.56 & 0.50 & \\
\hline Enhanced service quality & 4.46 & 0.50 & \\
\hline Enhanced visitor satisfaction & 4.50 & 0.50 & \\
\hline Dimension 3: social welfare & 4.64 & 0.38 & 0.85 \\
\hline Enhanced quality of life & 4.43 & 0.49 & \\
\hline $\begin{array}{l}\text { Increased entertainment } \\
\text { opportunity }\end{array}$ & 4.78 & 0.42 & \\
\hline $\begin{array}{l}\text { Increased events and } \\
\text { activities }\end{array}$ & 4.77 & 0.42 & \\
\hline $\begin{array}{l}\text { Enhanced satisfaction with } \\
\text { facilities }\end{array}$ & 4.60 & 0.49 & \\
\hline
\end{tabular}

Finally, the urban sustainability statements outlined in Table 4 indicate a high level of agreement of "transport efficiency" ( $\mathrm{M}=4.46)$ and "living comfort" $(\mathrm{M}=4.43)$. Items with lower mean scores were associated with "ecological sustainability" and "education" indicators.

$\underline{\text { Table 4. Mean, standard deviation, and reliability of urban sustainability }}$

\begin{tabular}{llll}
\hline Items & M & SD & $\begin{array}{l}\text { Cronbach's } \\
\alpha\end{array}$ \\
\hline Urban sustainability & & & 0.83 \\
Ecological sustainability & 4.19 & 0.52 & \\
Economic efficiency & 4.24 & 0.46 & \\
Environmental loading & 4.20 & 0.52 & \\
Living comfort & 4.43 & 0.49 & \\
Transport efficiency & 4.46 & 0.50 & \\
Environmental management & 4.23 & 0.42 & \\
Social welfare and public & 4.24 & 0.62 & \\
safety & & & \\
Education & 4.17 & 0.48 & \\
\hline
\end{tabular}

\section{Results for hypotheses testing}

All hypothesised effects were tested using regression equations. Means of dimensions and constructs were used to estimate the effects of mega-event impacts on the urban sustainability. We used four models to test H1-H3. First, after estimating Model 1, we regressed urban sustainability on the dimension of mega-event economic impact to test H1. The result demonstrated that "economic benefits" $(\beta=0.906)$ and "investment benefits" $(\beta=0.266)$, exerted significant positive effects on urban sustainability $\left(R^{2}=0.307, \mathrm{~F}=8.625\right)$. Thus, H1 was partially supported. Second, for Model 2, we regressed urban sustainability on the dimension of mega-event environmental 
ENTREPRENEURSHIP AND SUSTAINABILITY ISSUES

ISSN 2345-0282 (online) http://jssidoi.org/jesi/

2020 Volume 7 Number 3 (March)

http://doi.org/10.9770/jesi.2020.7.3(15)

impact to test $\mathrm{H} 2$. The analysis results for Model 2 showed that "infrastructure development" $(\beta=0.321)$ and "protection of natural resources and cultural heritage" $(\beta=0.620)$ exerted significant positive effects on urban sustainability $\left(R^{2}=0.466, \mathrm{~F}=21.071\right)$. Thus, $\mathrm{H} 2$ was partially supported. Third, for Model 3 , we regressed urban sustainability on the dimension of mega-event social impact to test H3. The analysis results for Model 3 showed that "social welfare" $(\beta=0.540)$ exerted significant positive effects on urban sustainability $\left(R^{2}=0.294, \mathrm{~F}=10.572\right)$. Thus, H3 was partially supported. Eventually, mega-event economic impact, environmental impact, and social impact were incorporated into the regression model as independent variables to assess Model 4 . The analysis results showed that mega-event environmental impact $(\beta=0.368)$, and mega-event social impact $(\beta=0.482)$ exerted significant positive effects on urban sustainability $\left(R^{2}=0.585, \mathrm{~F}=33.401\right)$. Consequently, the results suggest that mega-event environmental impact and social impact are critical predictors of urban sustainability. Table 5 summarises the results of all models for predicting urban sustainability.

Table 5. Regression results for predicting urban sustainability

\begin{tabular}{|c|c|c|c|c|}
\hline Independent variables & $\begin{array}{l}\text { Model } 1 \\
\text { (Std } \beta)\end{array}$ & $\begin{array}{l}\text { Model } 2 \\
\text { (Std } \beta)\end{array}$ & $\begin{array}{l}\text { Model 3 } \\
\text { (Std } \beta)\end{array}$ & $\begin{array}{l}\text { Model } 4 \\
\text { (Std } \beta\end{array}$ \\
\hline \multicolumn{5}{|l|}{ Economic impact } \\
\hline Economic benefits & $0.906 * *$ & & & \\
\hline Investment benefits & $0.266 * *$ & & & \\
\hline Prices rising & 0.073 & & & \\
\hline Wasting investment & $-0.759 * *$ & & & \\
\hline \multicolumn{5}{|l|}{ Environmental impact } \\
\hline Infrastructure development & & $0.321 * *$ & & \\
\hline Tourism infrastructure development & & -0.012 & & \\
\hline Protection of natural resources and cultural heritage & & $0.620 * *$ & & \\
\hline \multicolumn{5}{|l|}{ Social impact } \\
\hline Community development & & & -0.122 & \\
\hline Service and reception & & & 0.142 & \\
\hline Social welfare & & & $0.540 * *$ & \\
\hline Economic impact & & & & -0.025 \\
\hline Environmental impact & & & & $0.368 * *$ \\
\hline Social impact & & & & $0.482 * *$ \\
\hline$R^{2}$ & 0.307 & 0.466 & 0.294 & 0.585 \\
\hline $\mathrm{F}$ & 8.625 & 21.071 & 10.572 & 33.401 \\
\hline
\end{tabular}

\section{Results and Conclusions}

The reason for the interview was to identify companies with increased revenues and occupancy rate during the Formula 1 Grand Prix. The number of respondents is low because in this research was selected only the companies which increased occupancy rate and revenues during the Formula 1 Grand Prix event, but the research reveals important findings. The mean values of all dimensions and indicators were between neutral (3) and agree (4). Respondents identified these indicators for mega-event impact of the Formula 1 Grand Prix and urban sustainability of Baku city. The "increased number of tourists" was the indictor for which the mean value was 4.73 higher than agree (4). This showed that the increased number of tourists made a profound impression on Baku tourism stakeholders after the Formula 1 Grand Prix because it was a short-term phenomenon. For economic impact, the respondents perceived that the Formula 1 Grand Prix carries the potential to make substantial and lasting contributions, both positive and negative, to host destinations. For example, the majority of respondents perceived economic benefits and investment benefits from the event but suffered from rising prices and wasted investment. The mean values of indicators for prices rising and wasting investment were higher than the indicators for investment benefits. Respondents expressed positive impressions of the event for environmental 


\section{ENTREPRENEURSHIP AND SUSTAINABILITY ISSUES}

ISSN 2345-0282 (online) http://jssidoi.org/jesi/

2020 Volume 7 Number 3 (March)

http://doi.org/10.9770/jesi.2020.7.3(15)

impact and social impact. The statistics showed that positive dimensions (i.e. economic benefits, investment benefits) of economic impact exerted significant positive effects on urban sustainability, whereas all negative dimensions (i.e. rising prices and wasted investment) exerted nonsignificant effects on urban sustainability. Increased numbers of tourists and tourism revenues were the most significant indicators for mega-event economic impact. The statistics showed that dimensions (i.e. infrastructure development, protection of natural resources and cultural heritage) of environmental impact exerted significant positive effects on urban sustainability. Because certain indicators, such as improved city appearance and city road conditions and restored cultural heritage and historical buildings, are explicit works that are easily perceived by Baku residents and tourism stakeholders. The statistics showed that only one dimension (i.e., social welfare) of social impact exerted significant positive effects on urban sustainability, whereas dimensions (i.e. community development, service and reception) exerted nonsignificant effects on urban sustainability.

Impact studies of mega-events have recently focused on sustainability and their social, economic and environmental dimensions. In sum, statistics showed that only positive dimensions of economic, social, environmental impacts exert significant influences on urban sustainability (Jago et al, 2010; Deery and Jago, 2010; Kim et al, 2010; Fourie and Spronk, 2011; Lorde, Greenidge and Devonish, 2011; Ma et al, 2011). Compared to previous studies, in this research, the results suggest that mega-event economic impact is not critical predictor of urban sustainability. Hosting the mega-event is viewed as symbolic of the renewed strength of the city if the government can provide an enhanced vision of how to use these facilities afterwards. Unfortunately, mega-events have negative effects such as prices rising, wasting investment. Despite the potential for negative effects, decisions for hosting mega-events in the city are often made to benefit urban residents. Therefore, the government is encouraged to host mega-events if certain appropriate measures can be put into practice to address and reduce resident concerns regarding wasting investment, construction costs, overcrowding in public facilities, possible price increases (increased prices of goods and services, increased prices of real estate), and traffic congestion, all of which were observed to be the primary indicators determining the negative perceptions of residents.

The hosting of a mega-event should not be seen as an "end in itself" but rather part of a longer-term development plan or positioning strategy. Mega-events are an important way to catch social, economic, environmental goals and provide benefits for the societies and destinations. These events and activities improved city appearance and city road conditions and restored cultural heritage and historical buildings, enhanced and improved sanitation facilities, enhanced service quality, increase entertainment opportunities and activity participation for community residents, and enhance their quality of life and satisfaction with facilities, further providing higher social welfare. On the other hand, it affected residents lives negatively. Therefore, we strongly recommend that future megaevent host cities and tourism stakeholders take into consideration negative effects of mega-events. It is critical to calculating infrastructure investment to avoid wasting investment. Mega-events frequently face transport challenges which can have massive environmental impacts. Host cities have to reduce transport challenges. Hosting sports mega-events can create a great amount of waste and pollution. It is necessary to take measures to avoid such negative consequences, which otherwise can be detrimental in the long term to the wider host city environment. Therefore, event planners and city governments need to react proactively to this challenge.

At a time when public and private agencies recognise the importance of sustainable development, the economic, social and environmental impacts of mega-events are commanding increasing attention. Therefore, the current research contributes to the literature. Previous studies was limited to only one evaluated channel of resident perceptions. The evaluation and analysis of stakeholders contribute substantially to an enhanced understanding of impact and sustainability. The current study makes significant contributions to knowledge and practice in this field. First, this study evaluated mega-event impact and urban sustainability through stakeholder perceptions. Second, this research contributes to policymakers by revealing the impacts of mega-events on urban sustainable development. Third, our current research demonstrated negative impacts of mega events and policymakers who 


\section{ENTREPRENEURSHIP AND SUSTAINABILITY ISSUES}

ISSN 2345-0282 (online) http://jssidoi.org/jesi/

2020 Volume 7 Number 3 (March)

http://doi.org/10.9770/jesi.2020.7.3(15)

plan to host large events are likely to generate large economic, social and environmental benefits by reducing negative impacts of mega-events. Finally, the mega-event positive economic impact statements outlined in research indicate a high level of agreement, so the results of the research might encourage the government to bid and host mega-events.

\section{Research suggestions}

A multi-source measurement from stakeholders including residents, visitors, policymakers and the government would make the impact and sustainability assessment more reasonable and applicable. We strongly recommend that future studies take into account this suggestion and adopt multi-source measurement. Moreover, some variables (for example, enhance construction of infrastructure and improve road condition for the disabled, to ensure the participation of disabled people, improve social responsibility during mega-events, increase green labels and increase green purchases in developing countries) that may affect the residents' perception of urban sustainability or moderate the relationship between mega-event impact and urban sustainability are not included in this study. Future studies may consider these variables to provide more sophisticated evidences about how megaevent impacts affect urban sustainability.

\section{References}

Abrahams, G. 2017. Constructing definitions of sustainable development. Smart and Sustainable Built Environment 6(1): 34-47. https://www.emerald.com/insight/content/doi/10.1108/SASBE-03-2017-0009/full/html?fullSc=1

Absalyamov, T. 2015. The influence of cultural and sport mega-events on sustainable development of the city. Procedia - Social and Behavioral Sciences 188: 197-201. http://dx.doi.org/10.1016/j.sbspro.2015.03.372

Akbulaev, N.; \& Mirzayeva, G. 2020. Analysis of a Paired Regression Model of The Impact of Income from International Tourism on The Foreign Trade Balance, African Journal of Hospitality, Tourism and Leisure, 9 (1): 1-13.

Ahmadov, F. 2010. Azerbaycan'ın Ulusal Rekabet Gücü: TOWS ve Elmas Modelli Bir Çözümleme, Doctoral Thesis, Sakarya University

Allen, J.; O’Toole, W.; Harris, R.; \& Mcdonnel, I. 2010. Festival and Special Event Management, Wiley Australia Tourism Series.

Broudehoux, A. 2017. Mega-Events and Urban Image Construction; Beijing and Rio de Janeiro, Routledge.

Caiazza, R.; Audretsch, D. 2015. Can a Sport Mega-Event Support Hosting City's Economic, Socio-Cultural and Political Development?, Tourism Management Perspectives 14: 1-2. http://dx.doi.org/10.1016/j.tmp.2015.01.001

Dalevska, N.; Khobta, V.; Kwilinski, A.; \& Kravchenko, S. 2019. A Model for Estimating Social and Economic Indicators of Sustainable Development. Entrepreneurship and Sustainability Issues 6(4):1839-1860. http://doi.org/10.9770/jesi.2019.6.4(21)

Deery, M.; \& Jago, L. 2010. Social impacts of events and the role of anti-social behaviour. International Journal of Event and Festival Management, 1 (1):8-28. http://doi.org/10.1108/1785295101102928

Ekber, Ş.; \& Mirzayeva, G. 2017. Azerbaycan'da İç Turizmin Yerel Turistler Tarafindan Değerlendirilmesi, Uluslararası Türk Dünyası Turizm Araştırmaları Dergisi, 2 (1): 1-14.

Etiosa, O. 2012. The Impacts of Event Tourism on Host Communities Case: the City of Pietarsaari. Central Ostrobothnia University of Applied Sciences,

https://www.theseus.fi/bitstream/handle/10024/43714/omoregie_etiosa.pdf?sequence=1 


\section{ENTREPRENEURSHIP AND SUSTAINABILITY ISSUES}

ISSN 2345-0282 (online) http://jssidoi.org/jesi/

2020 Volume 7 Number 3 (March)

http://doi.org/10.9770/jesi.2020.7.3(15)

Fourie, J.; Gallego, M. S. 2011. The impact of mega-sport events on tourist arrivals. Tourism Management 32: 1364-1370. http://dx.doi.org/10.1016/j.tourman.2011.01.011

Fourie, J.; \& Spronk, K. 2011. South African mega-sport events and their impact on tourism. Journal of Sport and Tourism, $16(1)$ : 5-97. https://doi.org/10.1080/14775085.2011.576119

Getz, D. 2008. Event tourism: Definition, evolution, and research. Tourism Management 29: 403-428. https://www.sciencedirect.com/science/article/pii/S0261517707001719

Grix, J.; 2014. Leveraging Legacies from Sports Mega-Events: Concepts and Cases, Palgrave Macmillan.

Hall, C. M. 1992. Hallmark tourist events: Impacts, management and planning. London: Belhaven Press.

Jago, L.; Dwyer, L.; Lipman, G.; van Lill, D.; \& Vorster, S. 2010. Optimising the potential of mega-events: an overview. International Journal of Event and Festival Management 1(3): 220-237. http://dx.doi.org/10.1108/17852951011078023

Kim, H. J.; Gursoy, D.; \& Lee, S. B. 2006. The impact of the 2002 World Cup on South Korea: comparisons of pre- and post-games. Tourism Management 27(1): 86-96. https://www.deepdyve.com/lp/elsevier/the-impact-of-the-2002-world-cup-on-south-koreacomparisons-of-pre-and-olGvIekbWI

Kim, S.S.; Park, J.Y.; \& Lee, J. 2010. Predicted economic impact analysis of a mega-convention using multiplier effects. Journal of Convention and Event Tourism 11(1): 42-61. https://doi.org/10.1080/15470140903574195

Kaplanidou, K.; Emadi, A.A.; Sagas, M.; Diop, A.; \& Fritz, G. 2016. Business legacy planning for mega events: The case of the 2022 World Cup in Qatar. Journal of Business Research 69: 4103-4111. http://dx.doi.org/10.1016/j.jbusres.2016.03.041

Lamberti, L.; Noci, G.; Guo, J.; \& Zhu, S. 2011. Mega-events as drivers of community participation in developing countries: The case of Shanghai World Expmwlo. Tourism Management 32: 1474-1483. https://www.cabdirect.org/cabdirect/abstract/20113269953

Lorde, T.; Greenidge, D.; \& Devonish, D. 2011. Local residents' perceptions of the impacts of the ICC Cricket World Cup 2007 on Barbados: comparisons of pre- and post-games. Tourism Management 32(2): 349-356.

Lee, J. S.; Lee, C.; \& Park, C. 2014. Developing and validating a multidimensional quality scale for mega-events. International Journal of Hospitality Management 43: 121-131. http://dx.doi.org/10.1016/j.ijhm.2014.09.003

Liang, Y.; Wang, C.; Tsaur, S.; Yen, C.; \& Tu, J. 2016. Mega-event and urban sustainable development. International Journal of Event and Festival Management 7(3): 152-171.

https://www.emerald.com/insight/content/doi/10.1108/IJEFM-05-2016-0033/full/html?fullSc=1

Ma, S. C.; Egan, D.; Rotherham, I.; \& Ma, S.-M. 2011. A framework for monitoring during the planning stage for a sports mega-event. Journal of Sustainable Tourism 19(1):79-96. http://blogs.napier.ac.uk/qatar2022/wp-content/uploads/sites/29/2015/06/A-framework-formonitoring-during-the-planning.pdf

Maiello, A.; Pasquinelli, C. 2015. Destruction or construction? A (counter) branding analysis of sport mega-events in Rio de Janeiro, Cities 48: 116-124. http://dx.doi.org/10.1016/j.cities.2015.06.011

Matheson, V. A. 2006. Mega-events: The effect of the world's biggest sporting events on local, regional and national economies. College of the Holy Cross, Dept. Of Economics Faculty Research Press 06-10. https://crossworks.holycross.edu/econ_working_papers/68/?utm_source=crossworks.holycross.edu\%2Fecon_working_papers\%2F68\&utm _medium=PDF\&utm_campaign=PDFCoverPages

Menezes, T. R.; Souza, J. F. 2014. Transportation and urban mobility in mega-events: The case of Recife, Procedia - Social and Behavioral Sciences 162: 218 - 227. http://dx.doi.org/10.1016/j.sbspro.2014.12.202

Morse, S. 2008. Post-sustainable development. Sustainable $\quad$ Development 16(5): $341-352$. https://onlinelibrary.wiley.com/doi/pdf/10.1002/sd.354 


\section{ENTREPRENEURSHIP AND SUSTAINABILITY ISSUES}

ISSN 2345-0282 (online) http://jssidoi.org/jesi/

2020 Volume 7 Number 3 (March)

http://doi.org/10.9770/jesi.2020.7.3(15)

Mills, B. M.; Rosentraub, M.S. 2013. Hosting mega-events: A guide to the evaluation of development effects in integrated metropolitan regions, Tourism Management 34:238e246. http://dx.doi.org/10.1016/j.tourman.2012.03.011

Ntloko, N. J.; \& Swart, K. 2008. Sport Tourism Event Impacts On The Host Community: A Case Study Of Red Bull Big Wave Africa. South African Journal for Research in Sport, Physical Education and Recreation 30(2): 79-93. https://www.ajol.info/index.php/sajrs/article/view/25991

Parkes, S. D.; Jopson, A.; \& Marsden, G. 2016. Understanding travel behaviour change during mega-events: Lessons from the London 2012 Games. Transportation Research 92: 104-119. http://eprints.whiterose.ac.uk/103379/

Parkes, O.; Lettieri, P.; \& Bogle, D. L. 2016. Defining a quantitative framework for evaluation and optimisation of the environmental impacts of mega-event projects. Journal of Environmental Management 167: 236-245. http://dx.doi.org/10.1016/j.jenvman.2015.11.009

Pereira, L. F.; Albuquerque, M. S.; \& Portugal, L. S. 2014. Access of wheelchair users in sportive mega events: the case of Confederation Cup. Procedia - Social and Behavioral Sciences 162: 148 - 157. http://dx.doi.org/10.1016/j.sbspro.2014.12.195

Perla, R. J; Provost, L. P. 2012. Judgment Sampling: A Health Care Improvement Perspective. Quality Management in Health Care 21(3): 17-176. http://dx.doi.org/10.1097/QMH.0b013e31825e8806

Prakash, R.; Garg, P. 2019. Comparative assessment of HDI with Composite Development Index (CDI). Insights into Regional Development 1(1): 58-76. https://doi.org/10.9770/ird.2019.1.1(5)

Redclift, M. 2005. Sustainable development (1987-2005): an oxymoron comes of age. Sustainable Development 13(4): 212-227. https://onlinelibrary.wiley.com/doi/abs/10.1002/sd.281

WCED. 1987. Our Common Future. Oxford: Oxford University Press.

Werner, K.; Dickson, G.; \& Hyde, K.F. 2015. The impact of a mega-event on inter-organisational relationships and tie strength: Perceptions from the 2011 Rugby World Cup. Sport Management Review 18: 421-435. http://dx.doi.org/10.1016/j.smr.2014.11.005

Wu, Y.; Li, X.; \& Lin, G. C. S. 2016. Reproducing the city of the spectacle: Mega-events, local debts, and infrastructure-led urbanization in China, Cities journal 53: 51-60.

https://www.researchgate.net/publication/291424250 Reproducing the city of the spectacle Megaevents_local_debts_and_infrastructure-led_urbanization_in_China

Zhou, Y.; Ap, J. 2009. Residents' perceptions towards the impacts of the Beijing 2008 Olympic Games. Journal of Travel Research 48(1): 78-91.

https://www.researchgate.net/publication/249701302_Residents'_Perceptions_towards_the_Impacts_of_the_Beijing_2008_Olympic_Game $\underline{\mathrm{S}}$

Gulnar MIRZAYEVA

ORCID ID: 0000-0002-4531-1000

Oguz TURKAY

ORCID ID: 0000-0002-0752-6799

Nurhodja AKBULAEV

ORCID ID: 0000-0003-4271-9550

Fariz AHMADOV

ORCID ID: 0000-0003-2042-9018

Copyright (C) 2020 by author(s) and VsI Entrepreneurship and Sustainability Center

This work is licensed under the Creative Commons Attribution International License (CC BY). http://creativecommons.org/licenses/by/4.0/

CC) (i) Open Access 